\title{
SEED COLLECTION DATA ENCOMPASSING HALF OF THE VASCULAR FLORA OF THE PANNONIAN ECOREGION STORED BY THE PANNON SEED BANK
}

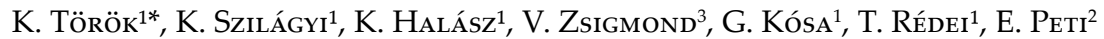 \\ J. SChellenberger ${ }^{2}$, Z. Tóth ${ }^{4}$ and K. SZitÁR ${ }^{1}$ \\ ${ }^{1}$ Centre for Ecological Research, Institute of Ecology and Botany, Hungarian Academy of Sciences \\ H-2163 Vácrátót, Alkotmány u. 2-4, Hungary \\ E-mails: *torok.katalin@okologia.mta.hu, szilagyi.krisztina@okologia.mta.hu \\ halasz.krisztian@okologia.mta.hu,kosa.geza@okologia.mta.hu \\ redei.tamas@okologia.mta.hu,szitar.katalin@okologia.mta.hu \\ ${ }^{2}$ Centre for Plant Diversity, H-2766 Tápiószele, Külsőmező 15, Hungary \\ E-mail: pannonmagbank@mail.nodik.hu, schellenberger.jx@gmail.com \\ ${ }^{3}$ Budapest Zoo and Botanical Garden, H-1146 Budapest, Állatkerti körút 6-12, Hungary \\ E-mail: zsigmond@zoobudapest.com \\ ${ }^{4}$ Eötvös Loránd University, H-1053 Budapest, Egyetem tér 1-3, Hungary \\ E-mail: tothz9@ludens.elte.hu
}

(Received 13 November, 2015; Accepted 30 May, 2016)

Seed bank collections have multiple benefits: store genetic material for conservation and research, and their data can also provide valuable scientific information. The Pannon Seed Bank was established during an EU LIFE+ project between 2010 and 2014 with the target to collect and store seeds of approx. 50\% of the wild native vascular flora of the Pannonian Biogeographic Region, seed accessions of at least 800 storable species. This task was fully achieved by the end of the project, as altogether 1,853 seed accessions of 910 species are stored. The aim of the present paper is to provide access to the collection data and metadata of the Pannon Seed Bank as it was completed by the end of the project. The collection campaign involved about 40 experts and covered the whole country. Collection and storing applied standard methodology, based on the ENSCONET project. The collection data published in this paper can be used manifold. Geographical data on species occurrences are major input for nature conservation and research. Seed collection date is valuable for ecological studies of phytophagous insects, frugivorous birds and mammals, etc. The database can be partner to international databases (like GBIF) or research infrastructures (e.g. LifeWatch). Hopefully, this data paper will contribute to further motivate the development of native seed collections and their use for conservation and research in Hungary.

Key words: data paper, database entry, habitat type, occurrence, orthodox seeds, phenological data, seed collection, seed storing, UTM grid 


\section{INTRODUCTION}

Seed banking of wild plant species has gained importance in the light of global changes (Vitt et al. 2010). Although it is accepted that preventing loss and damage to species at their natural habitats is the first priority (Menz et al. 2013), off-site (ex situ) conservation must be complementary to ensure effective conservation and restoration (Merritt and Dixon 2011). Seed bank collections have multiple benefits, the most important are: supporting nature conservation in case of loss or degradation of endangered populations of rare species in their natural habitats, providing research and educational material for various use and archives of phenological and ecological data on the sampled populations.

Seed banks have been established mainly to protect wild plant species genetic material (Cochrane et al. 2007, Li and Pritchard 2009), thus supporting conservation of threatened plant species. The stored material can be used for reintroductions and help to overcome propagule limitation. However, the usual amount of seeds stored in seed banks is insufficient for large scale reintroductions. Therefore the need for restoration seed banks that could store tons of seeds has been formulated (Menz et al. 2013, Merritt and Dixon 2011). Present seed banks can provide a source and methodology for the propagation of this scale of seed provision. Acknowledging the increasing role of seed bank collections of wild species in reintroduction, Hay and Probert (2013) published a review to guide the management and use of wild species collections in seed banks.

Ex situ collections are also used in research either on the species itself (Jayasuriya et al. 2013, Mondoni et al. 2011, Newton et al. 2013, Way 2003) or to reach back in time, e.g. to assess ecosystem service decline (Molnár et al. 2015) or climate change. The limited availability of long-term observations on the phenology of species has been a major impediment. Herbarium specimens have provided evidence on the warming climate by earlier flowering times (Primack et al. 2004). Significant scientific value can be attributed to the botanical occurrence records of these repositories as well (Clark and Thompson 2004). Given the usually narrow window of opportunity to collect viable seeds of wild plants (Hay and Probert 2013), the date of collection has a high indicator value for the phenology of species in a given habitat for the given year. Other data types recorded during seed collection on e.g. habitat type, population size or locality data are also valuable (Kattge et al. 2011, Klimešová and de Bello 2009, Kühn et al. 2004, Poschlod et al. 2003). Their use in ecological studies has expanded over the last decades (Bekker et al. 2007, Biesmeijer et al. 2006, Helsen et al. 2015, Kelemen et al. 2015). The importance of data papers has therefore increased, as a unique type of articles, used to present large data 
sets accompanied by metadata, which describes the content, context, quality and structure of the data (Chavan et al. 2011, Reichman et al. 2011, Soranno et al. 2015).

The present report is a data paper on the accessions of the Pannon Seed Bank (hereafter referred to as PSB). The PSB was initiated in 2006 (Zsigmond and Csontos 2006) and established in the frame of an EU LIFE+ project between 2010 and 2014 with the target to collect and store seeds of approx. 50\% of the storable native vascular flora of the Pannonian Biogeographic Region, accessions of at least 800 species. The aim of the present paper is to describe the applied seed collection methodology and to provide access to the collection and metadata of PSB.

\section{MATERIAL AND METHODS}

A key feature of the Pannonian Ecoregion is a mixed climatic effect that resulted in the development of its special biota. The region is situated at the forest-steppe ecotone, at its westernmost occurrence, representing a transitional region between temperate grasslands and closed temperate woodlands (Illyés and Bölöni 2007). The complex landscape hosts a great diversity of habitat types (Sundseth 2009). The Great Hungarian Plain is surrounded by hills and mountains as well as crossed by rivers that provide diverse habitats for several endemic species. Inland sand dunes, sand steppes, loess grasslands, saline-sodic grasslands and steppe forests are parts of a unique landscape configuration that does not occur in either Western or Northern Europe. The high proportion of endemic species contributes to its natural values, still outstanding compared to other parts of Europe (Batáry et al. 2010). A significant proportion of this variable and rich flora was planned to be sampled and stored by the PSB.

The 1,842 taxa as target of collection were selected from approx. 2,200 native vascular plant species occurring in the Pannonian Ecoregion based on the following priorities:

- species with orthodox seeds (if known according to Schermann 1967);

- species with probably orthodox seeds (based on information on relatives);

- protected, strictly protected and endemic species;

- species with known ecological importance as character species of communi-

ties or indicators of threatened habitat types (e.g. wetlands);

- relatives of species of economic importance (e.g. fodder, medicinal herbs);

- species of dry habitats, dominant forest herb layer species and rare arable weeds.

More than 40 experts, including researchers and rangers of national park directorates contributed to the collection during the project period. The seed 
Table 1

List of entries in the PSB collection data table, included in the online Supplement

\begin{tabular}{cl}
\hline No. & Entry name (as columns) \\
\hline 1 & genus name in Latin \\
3 & species name in Latin* \\
4 & author \\
5 & subtaxa name \\
6 & subtaxa author \\
7 & family name \\
8 & date of collection \\
9 & country of collection \\
10 & ÁNÉR** habitat type(s) of collection location \\
11 & elevation a.s.l. in m \\
12 & 10 km $\times 10$ km UTM grid code of the location \\
13 & coarse scale landscape code** of sampling point \\
14 & medium scale landscape code of sampling point \\
15 & fine scale landscape code of sampling point \\
16 & name of the fine scale landscape unit \\
17 & population size estimate (in categories from 1-6) \\
18 & specimen number used for the collection (in categories from 1-5) \\
\hline
\end{tabular}

* = species are named according to Király (2009); ${ }^{* *}=$ the habitat categories of Bölöni et al. $(2011)$ are used; ${ }^{* * *}=$ the codes of geographical regions of Hungary are applied based on Király et al. (2008)

collecting methodology was based on FAO Gene Bank standards, further developed by the ENSCONET (2009a) project, and adapted to the Pannonian Ecoregion during the LIFE project (Zsigmond 2011). A standard sample contained at least 5,000 seeds collected from at least 50 seed parent plants in a population, selected either randomly or systematically. A standard data sheet with information on the sampled population, the locality, and habitat was used in the field; the taxonomic identification was based on Király (2009). On-site photographs of the species and the habitat were later used for taxonomic verification. Seed samples with the data sheets were transported to the partner institutions for quality control. Data were archived and seeds cleaned only for the accessions passing the standard requirements of seed and data quality. Cleaning methods followed those of Rao et al. (2006) and ENSCONET (2009b). Seeds underwent viability analyses via germination tests. Methodology used and viability results of 24 species collected in more than 3 popula- 
tions are published in Peti et al. (2015). Before packaging in three layered, laminated pouches, seeds were dried in a drying chamber with temperature of $16 \pm 1^{\circ} \mathrm{C}$ and relative humidity of $15-20 \%$. Moisture content of the seeds was lowered to $3-7 \%$. Storing is carried out in base $\left(-20^{\circ} \mathrm{C}\right)$ and active $\left(5^{\circ} \mathrm{C}\right)$ storing facilities, both at two locations as duplicates (FAO 2014).

The data and meta-data collected in the present paper are based on the data sheet entries used by the collectors in the field. The strategy during the selection of the data to be published is based on the potential future usability for research and nature conservation. Table 1 lists the data types included for all species and accessions in the seed bank data table in the online Supplement. The table is organised according to the alphabetical order of Latin species names, as lines. Genus and species names are in separate entry columns to support searching. Hungarian species names are also inserted as nature conservation primarily uses these names in legislation. Collection date of seeds and the General Habitat Classification System code for the habitat (Bölöni et al. 2011) is also given for the accessions. The identification of the habitat type was done by the collector in the field based on the habitat identification guide (Bölöni et al. 2011). This can be occasionally transitional, covering more than one habitat type. Population size estimates are indicated in categories $(1=1$ specimen; $2=1-10 ; 3=11-100 ; 4=100-1,000 ; 5=1,000-10,000 ; 6=>10,000$ ). This data relates to the total population size, while the next entry gives estimation on the number of specimen sampled during the collection. Categories are: $1=1$ specimen; $2=2-10 ; 3=11-50 ; 4=50-100 ; 5=>100$.

Data also include geographic information of the accession: elevation, 10 $\mathrm{km} \times 10 \mathrm{~km}$ UTM grid code, and the name of landscape unit (based on Marosi and Somogyi 1990). UTM code is given only to locations within Hungary. The data table is available online as Supplement to this paper.

\section{RESULTS}

The aims of the project were over performed concerning the number of species and accessions collected. As a result of four years of collection activity, altogether 1,853 seed accessions of 910 species were stored by the end of 2014, including 364 samples of 204 protected species, and 76 samples of 45 strictly protected species. Concerning the distribution of plant families, the most sampled are Asteraceae, Poaceae, Caryophyllaceae, Fabaceae and Brassicaceae (42\% of total accessions), altogether 99 families are included in the PSB (Table 2). Most of the accessions represent frequent taxa, easy to collect, with large populations, like the genera Cirsium, Inula, Festuca, Bromus, Silene, Dianthus, Vicia and Astragalus. Non-viable seeds in the Poaceae family and seed predation of Asteraceae, Caryophyllaceae and Fabaceae lowered the number of appropriate seed samples. 
Table 2

Number of genera, species and accessions in plant families of the PSB collection (Peti et al. 2015)

\begin{tabular}{rlccc}
\hline & Family & Genus & Species & Accessions \\
\hline 1 & Asteraceae & 51 & 111 & 246 \\
2 & Poaceae & 45 & 94 & 190 \\
3 & Caryophyllaceae & 18 & 47 & 138 \\
4 & Fabaceae & 22 & 62 & 114 \\
5 & Brassicaceae & 30 & 48 & 97 \\
6 & Lamiaceae & 22 & 43 & 90 \\
7 & Apiaceae & 26 & 45 & 87 \\
8 & Scrophulariaceae & 13 & 34 & 79 \\
9 & Rosaceae & 16 & 28 & 70 \\
10 & Cyperaceae & 9 & 40 & 69 \\
11 & Orchidaceae & 16 & 32 & 65 \\
12 & Ranunculaceae & 7 & 27 & 46 \\
13 & Polygonaceae & 4 & 17 & 39 \\
14 & Boraginaceae & 13 & 20 & 33 \\
15 & Campanulaceae & 4 & 14 & 32 \\
16 & Further 84 families & 137 & 248 & 458 \\
\hline & Total & 433 & 910 & 1,853 \\
\hline
\end{tabular}

Spatial representation of sampling points matches less industrialised and cultivated areas, with most of the locations in the Great Hungarian Plain, the Transdanubian and the Northern Hungarian Mountains (Fig. 1). Sampling was slightly biased by collector preferences and domicile proximity, as usual in non-prescriptive sampling. Most of the accessions (75\%) originate from treeless habitats, $20 \%$ from forests and $5 \%$ from urban and cultivated areas. Among the open habitats dry grasslands represent $37 \%$ of samples, wet grasslands, wetlands and halophytic grasslands provided $18 \%, 5 \%$ and $5 \%$ of accessions, respectively. Collection in forests had a main focus on forest edges and clearings. Two third of collections were carried out in July, August and September. More detail on the statistics of samples can be found in Peti et al. (2015).

\section{DISCUSSION}

The establishment of the Pannon Seed Bank can be considered successful as it holds genetic samples from half of the native, storable seed bearing flora of the Pannonian Region. This is a major achievement, as beside the global 
Millennium Seed Bank only few regional seed banks exist for wild species, holding such a diversity of samples. Experiences gained during this huge undertaking can serve further collections and seed bank establishment.

Practical experiences include the parallel handling of many experts and large sample sets to be rapidly processed. This was done through the appointment of primary seed sample deposit institutions that assured dry temporary storage. During high season (October-January) sufficient staff has to be available to ensure the rapid treatment of samples.

The applied collection strategy corresponds to recent developments concerning sampling sufficient genetic diversity from the selected population (Crossa and Vencovsky 2011). Participants of an international Workshop organised during the project also confirmed the general strategy and the scientific achievements of the PSB (Anonymous 2014). It has to be noted that the PSB has so far focused on the diversity of species in the collection instead of the diversity of genotypes of the same species. To increase the sampled populations can be a way forward for future collections. Collections are continued, however, in the lack of substantial funding, only a slow enrichment of the collection is foreseen.

The collection data published in this paper can be used manifold. Beside those mentioned in the Introduction, occurrence records may support nature conservation and are basis for research to link with zoological data (Batáry et al. 2010, Biesmeijer et al. 2006). Whenever Hungary decides to join the Global Biodiversity Facility (www.gbif.org) or the LifeWatch European Research In-

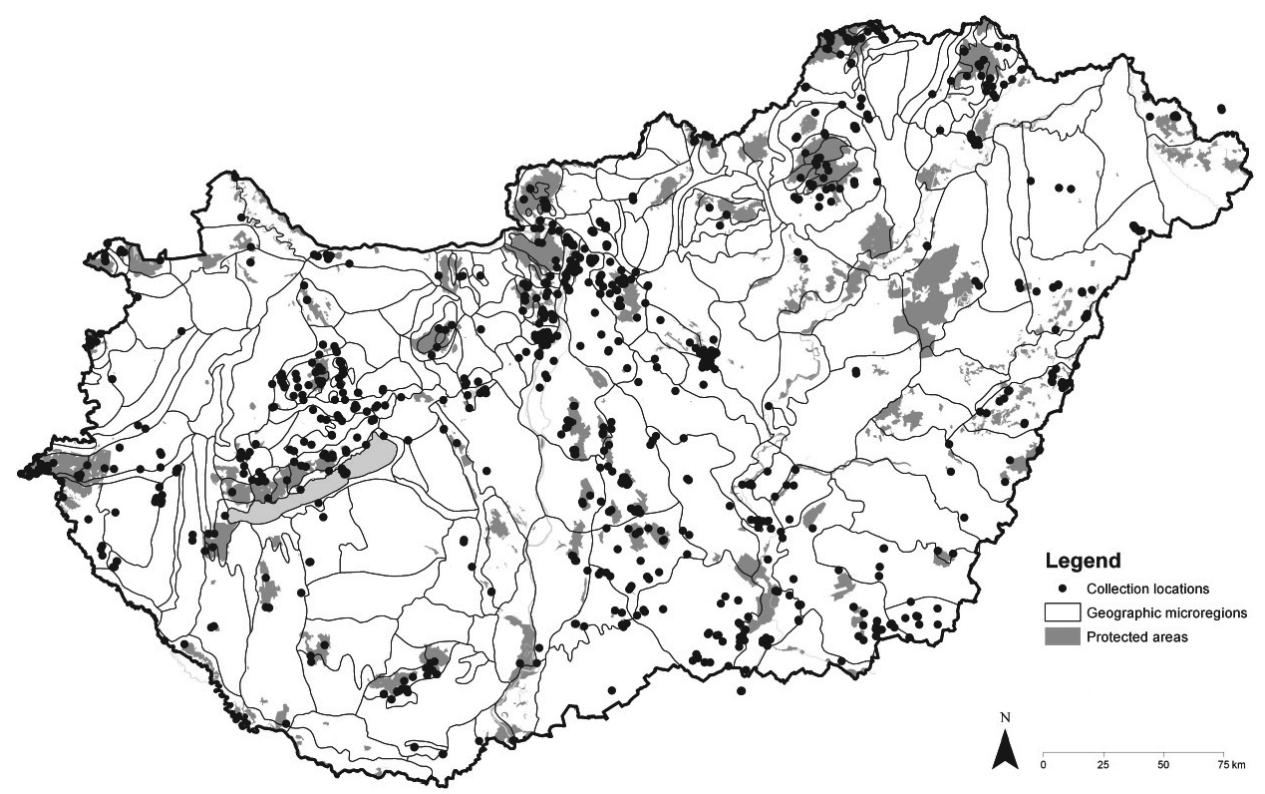

Fig. 1. Map of collection locations for the PSB in Hungary 
frastructure (www.lifewatch.eu), this database can serve as a major input. The Millennium Seed Bank and the Botanic Gardens Conservation International are major proponents of using native seeds in revegetation and restoration activities. The seed banks can provide seeds for further propagation that is required to produce sufficient seeds for reintroduction. A good example of this effort is the UK Native Seed Hub based on the Millennium Seed Bank collections, with a number of native seed growers. Several countries developed rules for the use of native seeds and their provenance requirements (Van der Mijnsbrugge et al. 2010) and identified seed zones (Anonymous 2015, Kiehl et al. 2014). Hopefully the publication of the collection data of PSB will contribute to further motivate the development of native seed use and database access in Hungary.

*

Acknowledgements - The project was supported by the European Commission LIFE programme and the Ministry of Agriculture (LIFE08/NAT/H/000288, HUSEEDBANK). The work of the project staff and that of all the collectors is highly acknowledged (for list of collectors see Peti et al. 2015).

\section{REFERENCES}

Anonymous (2014): Recommendations for the effective ex-situ conservation of the Pannonian wild flora by means of seed banking. - Adopted at the 1st International Workshop on Developing the Pannon Seed Bank, 24-25 February 2014, Vácrátót, Hungary). http:// www.pannonmagbank.hu/pmb/wp-content/uploads/2014/03/PSB-recomendations. pdf (Accessed 3 November 2015).

Anonymous (2015): National seed strategy for rehabilitation and restoration 2015-2020. - Plant Conservation Alliance. http://www.blm.gov/style/medialib/blm/wo/Planning_and_

Renewable_Resources/fish_wildlife_and/plants/seedstrategy.Par.66250.File.dat/ SeedStrategy081215.pdf (Accessed 3 November 2015).

Batáry, P., Báldi, A., Sárospataki, M., Kohler, F., Verhulst, J., Knop, E., Herzog, F. and Kleijn, D. (2010): Effect of conservation management on bees and insect-pollinated grassland plant communities in three European countries. - Agric. Ecosyst. Environ. 136: 35-39. http://dx.doi.org/10.1016/j.agee.2009.11.004

Bekker, R. M., van der Maarel, E., Bruelheide, H. and Woods, K. (2007): Long-term datasets: From descriptive to predictive data using ecoinformatics. - J. Veg. Sci. 18: 457462. http://dx.doi.org/10.1111/j.1654-1103.2007.tb02559.x

Biesmeijer, J. C., Roberts, S. P. M., Reemer, M., Ohlemüller, R., Edwards, M., Peeters, T., Schaffers, A. P., Potts, S. G., Kleukers, R., Thomas, C. D., Settele, J. and Kunin, W. E. (2006): Parallel declines in pollinators and insect-pollinated plants in Britain and the Netherlands. - Science 313: 351-354. http://dx.doi.org/10.1126/science.1127863

Bölöni, J., Molnár, Z. and Kun, A. (eds) (2011): Magyarország élóhelyei. A hazai vegetációtípusok leírása és határozója. ÁNÉR 2011. (Habitats of Hungary. Description and identification guide of Hungarian vegetation types). - MTA OOkológiai és Botanikai Kutatóintézete, Vácrátót, 441 pp. [in Hungarian] 
Chavan, V., Penev, L. and Settele, J. (2011): Ecology metadata as peer-reviewed data papers. - Science E-Letters online. http://www.sciencemag.org/content/331/6018/703/reply (Accessed 3 November 2015)

Clark, M. and Thompson, R. (2004): Botanical records reveal changing seasons in a warming world. - Australas. Sci. 25: 37-39.

Cochrane, J. A., Crawford, A. D. and Monks, L. T. (2007): The significance of ex situ seed conservation to reintroduction of threatened plants. - Aust. J. Bot. 55: 356-361. http:// dx.doi.org/10.1071/bt06173

Crossa, J. and Vencovsky, R. (2011): Basic sampling strategies: theory and practice. - In: Guarino, L., Ramanatha Rao, V. and Reid, R. (eds): Collecting plant genetic diversity: technical guidelines. CAB International on behalf of IPGRI in association with FAO/ IUCN/UNEP, Wallingford, $28 \mathrm{pp}$.

ENSCONET (2009a): ENSCONET Seed collecting manual for wild species. - Royal Botanic Gardens, Kew \& Universidad Politécnica de Madrid, 32 pp. http://ensconet.maich.gr/ PDF/Collecting_protocol_English.pdf (Accessed 3 November 2015).

ENSCONET (2009b): ENSCONET Curation protocols \& recommendations. - Royal Botanic Gardens, Kew, 45 pp. http://ensconet.maich.gr/PDF/Curation_protocol_English.pdf (Accessed 3 November 2015).

FAO (2014): Genebank standards for plant genetic resources for food and agriculture. - FAO, Rome, 182 pp. http://www.fao.org/3/a-i3704e.pdf (Accessed 3 November 2015).

Hay, F. R. and Probert, R. J. (2013): Advances in seed conservation of wild plant species: a review of recent research. - Conserv. Physiol. 1: 1-11. http://dx.doi.org/10.1093/conphys/cot030

Helsen, K., Hermy, M. and Honnay, O. (2015): Changes in the species and functional trait composition of the seed bank during semi-natural grassland assembly: seed bank disassembly or ecological palimpsest? - J. Veg. Sci. 26: 58-67. http://dx.doi.org/10.1111/ jvs. 12210

Illyés, E. and Bölöni, J. (eds) (2007): Lejtősztyeppek, löszgyepek és erdősztyepprétek Magyarországon. (Slope steppes, loess steppes and forest steppe meadows in Hungary). - MTA Ökológiai és Botanikai Kutatóintézete, Vácrátót, 234 pp. (in Hungarian)

Jayasuriya, K. M. G. G., Wijetunga, A. S. T. B., Baskin, J. M. and Baskin, C. C. (2013): Seed dormancy and storage behaviour in tropical Fabaceae: a study of 100 species from Sri Lanka. - Seed Sci. Res. 23: 257-269. http://dx.doi.org/10.1017/s0960258513000214

Kattge, J., Díaz, S., Lavorel, S., Prentice, I. C., Leadley, P., Bönisch, G., Garnier, E., Westoby, M., Reich, P. B., Wright, I. J., Cornelissen, J. H. C., Violle, C., Harrison, S. P., Van Bodegom, P. M., Reichstein, M., Enquist, B. J., Soudzilovskaia, N. A., Ackerly, D. D., Anand, M., Atkin, O., Bahn, M., Baker, T. R., Baldocchi, D., Bekker, R., Blanco, C. C., Blonder, B., Bond, W. J., Bradstock, R., Bunker, D. E., Casanoves, F., Cavender-Bares, J., Chambers, J. Q., Chapin III, F. S., Chave, J., Coomes, D., Cornwell, W. K., Craine, J. M., Dobrin, B. H., Duarte, L., Durka, W., Elser, J., Esser, G., Estiarte, M., Fagan, W. F., Fang, J., Fernández-Méndez, F., Fidelis, A., Finegan, B., Flores, O., Ford, H., Frank, D., Freschet, G. T., Fyllas, N. M., Gallagher, R. V., Green, W. A., Gutierrez, A. G., Hickler, T., Higgins, S. I., Hodgson, J. G., Jalili, A., Jansen, S., Joly, C. A., Kerkhoff, A. J., Kirkup, D., Kitajima, K., Kleyer, M., Klotz, S., Knops, J. M. H., Kramer, K., Kühn, I., Kurokawa, H., Laughlin, D., Lee, T. D., Leishman, M., Lens, F., Lenz, T., Lewis, S. L., Lloyd, J., Llusià, J., Louault, F., Ma, S., Mahecha, M. D., Manning, P., Massad, T., Medlyn, B. E., Messier, J., Moles, A. T., Müller, S. C., Nadrowski, K., Naeem, S., Niinemets, Ü., Nöllert, S., Nüske, A., Ogaya, R., Oleksyn, J., Onipchenko, V. G., Onoda, Y., Ordoñez, J., Overbeck, G., Ozinga, W. A., Patiño, S., Paula, S., Pausas, J. G., 
Peñuelas, J., Phillips, O. L., Pillar, V., Poorter, H., Poorter, L., Poschlod, P., Prinzing, A., Proulx, R., Rammig, A., Reinsch, S., Reu, B., Sack, L., Salgado-Negret, B., Sardans, J., Shiodera, S., Shipley, B., Siefert, A., Sosinski, E., Soussana, J.-F., Swaine, E., Swenson, N., Thompson, K., Thornton, P., Waldram, M., Weiher, E., White, M., White, S., Wright, S. J., Yguel, B., Zaehle, S., Zanne, A. E. and Wirth, C. (2011): TRY, a global database of plant traits. - Glob. Chang. Biol. 17: 2905-2935. http://dx.doi.org/10.1111/ j.1365-2486.2011.02451.x

Kelemen, A., Török, P., Valkó, O., Deák, B., Tóth, K. and Tóthmérész, B. (2015): Both facilitation and limiting similarity shape the species coexistence in dry alkali grasslands. - Ecol. Complexity 21: 34-38. http://dx.doi.org/10.1016/j.ecocom.2014.11.004

Kiehl, K., Kirmer, A., Shaw, N. and Tischew, S. (eds) (2014): Guidelines for native seed production and grassland restoration. - Cambridge Scholars Publishing, New Castle Upon Thyne, $301 \mathrm{pp}$.

Király, G. (ed.) (2009): Új Magyar Füvészkönyv. Magyarország hajtásos növényei. Határozókulcsok. (New Hungarian Herbal. The vascular plants of Hungary. Identification keys). - Aggtelek National Park Directorate, Jósvafó, 504 pp. (in Hungarian)

Király, G., Molnár, Z., Bölöni, J. and Vojtkó, A. (eds) (2008): Magyarország földrajzi kistájainak növényzete. (The actual vegetation of the Hungarian geographical microregions). MTA Ökológiai és Botanikai Kutatóintézete, Vácrátót, 248 pp.

Klimešová, J. and de Bello, F. (2009): CLO-PLA: the database of clonal and bud bank traits of Central European flora. - J. Veg. Sci. 20: 511-516. http://dx.doi.org/10.1111/j.16541103.2009.01050.x

Kühn, I., Durka, W. and Klotz, S. (2004): BiolFlor, a new plant-trait database as a tool for plant invasion ecology. - Divers. Distrib. 10: 363-365. http://dx.doi.org/10.1111/j.13669516.2004.00106.x

Li, D.-Z. and Pritchard, H. W. (2009): The science and economics of ex situ plant conservation. - Trends Plant Sci. 14: 614-621. http://dx.doi.org/10.1016/j.tplants.2009.09.005

Marosi, S. and Somogyi, S. (eds) (1990): Magyarország kistájainak katasztere I-II. (Inventory of natural microregions of Hungary I-II). - MTA Földrajztudományi Kutató Intézet, Budapest, 1023 pp.

Menz, M. H., Dixon, K. W. and Hobbs, R. J. (2013): Hurdles and opportunities for landscapescale restoration. - Science 339: 526-527. http://dx.doi.org/10.1126/science.1228334

Merritt, D. J. and Dixon, K. W. (2011): Restoration seed banks, a matter of scale. - Science 332: 424-425. http://dx.doi.org/10.1126/science.1203083

Molnár, V. A., Löki, V., Takács, A., Schmidt, J., Tökölyi, J., Bódis, J. and Sramkó, G. (2015): No evidence for historical declines in pollination success in Hungarian orchids. Appl. Ecol. Environ. Res. 13: 1097-1108. http://dx.doi.org/10.15666/aeer/1304_10971108

Mondoni, A., Probert, R. J., Rossi, G., Vegini, E. and Hay, F. R. (2011): Seeds of alpine plants are short lived: implications for long-term conservation. - Ann. Bot. 107: 171-179. http://dx.doi.org/10.1093/aob/mcq222

Newton, R. J., Hay, F. R. and Ellis, R. H. (2013): Seed development and maturation in early spring-flowering Galanthus nivalis and Narcissus pseudonarcissus continues postshedding with little evidence of maturation in planta. - Ann. Bot. 111: 945-955. http:// dx.doi.org/10.1093/aob/mct051

Peti, E., Málnási Csizmadia, G., Oláh, I., Schellenberger, J., Török, K., Halász, K. and Baktay, B. (2015): A Pannon Magbank program (2010-2014) maggyüjtési, tárolási, előzetes életképesség vizsgálati eredményei és módszerei. (Seed collecting and stor- 
ing and preliminary seed viability results and methods of the Pannon Seed Bank project (2010-2014)). - Term.véd. Közlem. 21: 215-231. (in Hungarian)

Poschlod, P., Kleyer, M., Jackel, A.-K., Dannemann, A. and Tackenberg, O. (2003): BIOPOP, a database of plant traits and internet application for nature conservation. - Folia Geobot. Phytotax. 38: 263-271. http://dx.doi.org/10.1007/bf02803198

Primack, D., Imbres, C., Primack, R. B., Miller-Rushing, A. J. and Del Tredici, P. (2004): Herbarium specimens demonstrate earlier flowering times in response to warming in Boston. - Amer. J. Bot. 91: 1260-1264. http://dx.doi.org/10.3732/ajb.91.8.1260

Rao, N. K., Hanson, J., Dulloo, M. E., Ghosh, K., Novell, D. and Larinde, M. (2006): Manual of seed handling in genebanks. Handbooks for Genebanks No. 8. - Biodiversity International, Rome, $147 \mathrm{pp}$.

Reichman, O. J., Matthew, B. J. and Schildhauer, M. P. (2011): Challenges and opportunities of open data in ecology science. - Science 331: 703-705. http://dx.doi.org/10.1126/ science.1197962

Schermann, S. (1967): Magismeret I-II. (Seed morphology I-II). - Akadémiai Kiadó, Budapest, 1074 pp. [in Hungarian]

Soranno, P. A., Cheruvelil, K. S., Elliott, K. C. and Montgomery, G. M. (2015): It's good to share: why environmental scientists' ethics are out of date. - BioScience 65: 69-73. http://dx.doi.org/10.1093/biosci/biu169

Sundseth, K. (2009): Natura 2000 in the Pannonian Region. - European Commission Environment Directorate General, Brussels, 12 pp. http://ec.europa.eu/environment/nature/ info/pubs/docs/biogeos/pannonian.pdf (Accessed 3 November 2015).

Van der Mijnsbrugge, K., Bischoff, A. and Smith, B. (2010): A question of origin: where and how to collect seed for ecological restoration. - Basic Appl. Ecol. 11: 300-311. http:// dx.doi.org/10.1016/j.baae.2009.09.002

Vitt, P., Havens, K., Kramer, A. T., Sollenberger, D. and Yates, E. (2010): Assisted migration of plants: changes in latitudes, changes in attitudes. - Biol. Conserv. 143: 18-27. http:// dx.doi.org/10.1016/j.biocon.2009.08.015

Way, M. J. (2003): Collecting seed from non-domesticated plants for long-term conservation. - In: Smith, R. (ed.): Seed conservation, turning science into practice. Royal Botanical Gardens, Kew, pp. 163-201.

Zsigmond, V. (ed.) (2011): Maggyüjtési útmutató. (Guideline for seed collecting). - In: Vadon élő növényfajok maggyưjtési stratégiája Magyarországon. Pannon Magbank Projekt. LIFE08/NAT/H/000288, HUSEEDBANK. 16 pp. http://botkert.hu/sites/botkert.hu/ files/PMB_Maggyujtesi-utmutato.pdf (Accessed 3 November 2015) (in Hungarian)

Zsigmond, V. and Csontos, P. (2006): Előkészületek a hazai természetes flóra magbanki megörzésére. (Preparations for seed banking of the Hungarian native flora). - In: Korsós, Z., Gyenis, G. and Penksza, K. (eds): Előadások összefoglalói, MBT XVI. Vándorgyűlés, 2006. november 9-11, Magyar Biológiai Társaság, Fővárosi Állat- és Növénykert, Budapest, pp. 183-190. 